\title{
Museum Training Programme in Turkey: Story of Friendship Train and Children's Education Rooms in the Museums
}

\author{
Ayşe Çakır İlhan', Müge Artar'1, Ayşe Okvuran1, Ceren Karadeniz² \\ ${ }^{1}$ Faculty of Education, Ankara University, Ankara, Turkey \\ ${ }^{2}$ Graduate School of Education, Ankara University, Ankara, Turkey \\ Email: ilhan@ankara.edu.tr, atacan99@hotmail.com, okvuran@education.ankara.edu.tr, \\ ckaradeniz@ankara.edu.tr
}

Received 13 September 2014; revised 29 September 2014; accepted 14 October 2014

Copyright $@ 2014$ by authors and Scientific Research Publishing Inc.

This work is licensed under the Creative Commons Attribution International License (CC BY). http://creativecommons.org/licenses/by/4.0/

(c) (i) Open Access

\begin{abstract}
Museum education has been developed in Turkey since the 1990s within theoretical and methodological framework to better serve educational activities in the museum environment. Within this context a Museum Training Programme ${ }^{1}$ was developed to make museums more functional, to create places children can enjoy visiting, to support children's creative skills, as well as, to facilitate participatory and sustained learning. The methods, techniques and activities practiced in these museum trainings took place in Ankara, Istanbul, Kars, Erzurum, Sivas, Erzincan and Eskisehir districts and were comprised of a variety of content that was developed into a "Museum Training Package". The components of this package include Adult and Peer Trainer Modules, a Museum Activity Book, as well as, Kars and Erzurum District Samples. Meanwhile it was important to expand upon the museum activities used by children. After the Museum Training Programme had been practiced a Museum and Friendship Train travelled from Istanbul to Kars and the project concluded with the opening of children's museum room in Erzurum and Kars. This study focuses on the whole process of Museum Training Programme including trainings, methods, techniques, interviews, train project, children's museum rooms and closure workshop.
\end{abstract}

\section{Keywords}

Museum Education, Peer Education, Cultural Heritage, Museum Education Train, Children's Museum

\footnotetext{
${ }^{1}$ The Museum Training Programme is based on cooperation between Ankara University Museum Training Department, Ministry of Culture and Tourism and Social Services and Child Protection Agency within the framework of the "UN Joint Programme on Alliances for Culture
} Tourism in Eastern Anatolia”. 


\section{Introduction}

The basic function of contemporary inclusive museums today is to be pleasing to society. Being more inclusive points out the efforts of museums to be better understood, preferred by people as a destination and more welcoming for all in society including the changing audiences of museums as students, stakeholders, parents, grandparents and families. All of them are willing to use the museums as learning institutions because museums offer free-choice learning environments which include experiences through emotions (Ambrose \& Paine, 2006). Life served by the museum has individual, social and physical aspects and covers a variety of elements such as; interaction with the objects by means of perceptions and interests, observation, expression of sentiments, using imagination, connecting with our own lives, being informed, seeing the message from the museum's point of view and interpreting, reading the objects, sharing cultural values and life, seeking the truth, making applications and evaluating (Hooper-Greenhill, 1999; Ambrose \& Paine, 2006; Weil, 1990).

Contemporary museums changed the modes, audiences, strategies, exhibition taxonomies, display techniques and visitor policies through 21st century's social change (Lyon,1999). Exhibitions in there become largely developed with the aid of professional designers, creative practitioners who borrow tools from advertising, a carefully crafted language, the focus group, formative evaluation and the survey. They also become multi-model, mixing a large variety of tools and techniques-combining exhibit script, objects, photography, graphics, media, interactivity, immersive sensory experiences, dramatic and directed lighting-all of which serves to stimulate the exploratory desires of the visitors. An increasing public interest in museums, a heightened role and renewed visibility for them in our societies is around. It is possible to say that the consumer culture gained a high level of self-consciousness and the notion of self is shaped by individual experiences rather than societal imperatives. This process caused a new way of thinking about visitor friendly museums. These museums make the visitor experiences more explorative, hands-on, sensory, emotional and energetic. According to Grek (2009) the postmodern museum has brought people closer to exhibitions than ever before; more and more visitors now engage with museum displays in much more participatory ways. These open and accessible institutions create the new notion. The notion of them does not signify a building to be visited, but a plethora of transient activities to be enjoyed within and without the museum; thus, it almost moves beyond the idea of the exhibition itself. Their audiences should be rediscovered. Indeed, due to a number of demographic and cultural trends in post-industrial and postmodern society, museums and galleries have arguably been changing from relatively elitist into more audience-driven and service-oriented organisations. Amongst an array of transformations and new orientations, their educational role has been receiving increased interest and acknowledgement (Grek, 2009; Schubert, 2000; Talboys, 2011; Keene, 2005).

At the core of museum education lies objects that "enable many different approaches to learning skills" through the involvement of all five senses. Museum objects can be presented in a variety of ways and by using these objects there is also the possibility of developing people' abilities far beyond language arts and mathematics education favored in classroom teaching (Gingell 2006). This more encompassing approach encourages museum visitors to expand upon the fundamental values of humanity, culture, and heritage. Also, by the end of this process people can increase their museum literacy as a form of educational attainment (Hooper-Greenhill, 1994, 2000; Talboys, 2006). Museum education is a process of preparing museum facilities, utilizing existing collections, and organizing visitor centered education programmes that arouse curiosity, interest and excitement; all in an effort to enable learning for visitors. Within the lifelong education process museum education comprises the effective usage of museums as learning based educational experiences. It is also the effort of understanding yourself and people within time and space, sustaining cultural heritage, as well as, significantly associating the past, present and future. Also, this includes understanding, preserving and keeping cultural properties, historical monuments and artworks alive.

\section{Museum Education in Turkey and Scope of Museum Training Programme}

In Turkey, the role of the museum in education took place only within governmental programs until the 1990s. The Ministry of National Education realized radical changes in educational curricula in the first decade of the $21^{\text {st }}$ century through a constructivist approach. In 2008, "museum and education" was introduced as an associated subject in primary education as well. The initial academic studies in Turkish museums began in the museums of Ankara, and the country's largest city, Istanbul (Ankara Museum of Anatolian Civilizations, İstanbul Modern: İstanbul Museum of Modern Art, İstanbul Archeological Museum and etc.) (İlhan, 2009). 
Besides contemporary educational approaches to curriculum, universities and non-governmental organizations have supported using museums as learning-by-doing centers by presenting academic studies, seminars, workshops, projects and so forth. This concept has also envolved into Teachers Training and Preschool Teaching Undergraduate Programmes (Karadeniz, 2012).

The main purpose of the Museum Training Programme is creating a educational programme for children and sustaining it in several museums throughout Turkey. This programme has been developed to make museums more functional, turning them into places that children can visit with pleasure, supporting creative skills in children and facilitating participatory and sustained learning. The programme is based on cooperation with the Ankara University Interdisciplinary Museum Education Department. The methods, techniques and activities used in museum trainings taking place in several provinces including Ankara, Istanbul, Kars, Erzurum, Sivas, Erzincan and Eskisehir were developed into a "Museum Training Package” comprising five different books of varying content as to provide a source of replicatable activities to be carried out in other parts of the country. Components of this package were prepared to inform teachers, museum staff and children about the process of developing awareness of their cultural heritage through peer training within museums and through subsequent extension work by children. With an aim of empowering children to use national and international values while also being aware of the importance of peace and tolerance and raising awareness which is their rights through peer education. The project also included these additional purposes: to help students to be encouraged to join cultural, educational and scientific activities, to create awareness in children of culture and museums, to help raising future museum audiences, to bring children in awareness of history, geography and different cultures and to extend the consciousness of museums and cultural heritage through use of a Friendship Train.

\section{Methodology}

Quantitative and qualitative methodologies were used through the project. 391 children participated the activities in severel museums in different cities throughout Turkey. This group consisted of children from varying socio-economic backgrounds and who were also in the supervision of Social Services and Ministy of Family and Social Policies. 84 adults participated in the museum trainings in eight different museums. Among the children participating 36 were leaders of children's rights committeess and trained as peer museum educators. They were informed to train the other children about museum education and were expected to guide other children during their museum visits. There was also an adult group that included 49 persons and consisted of representatives from the pilot provinces, museum administrators of these provinces, ministry of culture and tourism specialists and museum specialists who were responsible for education in the museums. While working on different learning environments in the project, multiple intelligence theory, constructivist approach to education, project approach, process evaluation assessment methods were used. All of these activities were dependent on three thematic backgrounds: "play, daily life and cultural heritage”. The main concepts and subjects that were themed in the activities were communication and social skills, motivation, learning in the museum, awareness education, human and children rights, children's participation, teaching cultural heritage, teaching cultural consciousness, teaching creative thinking and teaching tolerance. Peer educators and supervisory adults participated in the museum education practices which included activities such as warm up games in the pre-museum process. Also, the activities (seek-and-find game, timetable and dumb map, photograph and frozen image activitiy, thematic search, museum brochure, poster making and time capsule activities in the museum and assessment process) occurred during the post-museum process.

\section{Results and Discussion}

In Table 1 children described the museum instead of describing museum education. They emphasized the educational functions of the museums eventhough they did not attend any museum education activity before.

In Table 2 children emphasized the importance of interactivity and direct contact with the museum objects. According to them, museums should be often visited during history and social sciences courses. Before joining the museum education studies they identified museums as boring places to visit despite museums' educational and cultural functions. When thoughts on museum education were examined by content analysis, children were found to be distant with museum education, so they only explained their estimations and predictions about it. Museum trainings were applied in Museum of Anatolian Civilizations (Ankara), Sivas Archeology Museum (Sivas), Kayseri Archeology Museum (Kayseri), Kars Archeology Museum (Kars), Cartoon Museum (Eskişehir), 
Table 1. Ideas about museum education before the practices (pre-museum activities).

\begin{tabular}{lcc}
\hline \multicolumn{1}{c}{ Statement } & $\mathrm{f}$ & $\%$ \\
\hline Museum is an institution where ancient objects are preserved and exhibited. It represents art and history. & 98 & 49 \\
I was there before and I liked it. & 36 & 18 \\
I think museum education will be entertaining and useful. & 20 & 10 \\
I guess museum education will be tiring. & 19 & 9.5 \\
Museum education represents the process of selecting the museum objects and shows how to examine & 18 \\
them in the museum. & 5 & 2.5 \\
Museum education teaches the content of the museum. & 4 & 2 \\
I do not have any idea what museum education is. & Total & 200 \\
\hline
\end{tabular}

Table 2. Predictions on museum education activities before the practices.

\begin{tabular}{|c|c|c|}
\hline Statement & $\mathrm{f}$ & $\%$ \\
\hline $\begin{array}{l}\text { Museum education should start with the discussion on the functions of the museum and we should discuss } \\
\text { the description of museum education. }\end{array}$ & 16 & 31.3 \\
\hline Museums should be described as places which are full of joy and entertainment throughout the education. & 14 & 27.5 \\
\hline $\begin{array}{l}\text { People should be trained about their past, present and they should be made to transfer them to next genera- } \\
\text { tions. }\end{array}$ & 10 & 19.6 \\
\hline Objects can be examined better while people are touching them through interactive programmes. & 6 & 11.7 \\
\hline Museum education will complete history education at the curriculum level. & 5 & 9.8 \\
\hline Total & 51 & 100 \\
\hline
\end{tabular}

Erzurum Ataturk House Museum (Erzurum), Sabanci Museum (İstanbul) and Erzincan Museum (Erzincan).

An interactive educational module was prepared and applied at each of the project museums simultaneously. Module included warm-up games, time capsule activity, search-and-find activity (with cue cards), history line, mute map activity, poster and brochure preparation, frozen image activity and role play with role cards. The Warming Up stage was characterized by body movement, concurrent and intensive use of emotions, and inward looking exercises. It was geared toward creating group dynamics including building trust and ensuring harmony using enjoyable games. While the main aim of this stage was to create participant dynamics, it was also a preparation for the next stage of museum training. In these activities the aim was to have participants warm up by walking and to motivate them for the next activity by meeting the museum collections. Warming up games continued with the Frozen Image activity. During that activity children used their bodies to portray an image which clarified an object from the museum. In the second half of the activities, work was done creating a Time Caspsule. The trainer instructed participants that a time capsule was to be prepared to transfer certain objects from the museum to future generations. After a brief discussion, the trainer wanted participants to choose various objects belonging to different historical periods from the exhibition. Participants started discussing when these objects might have been used and for which purposes. At the end of the discussion, the trainer asked them to select three of these objects to be placed in a time capsule and to state their justification for selecting them in a table titled "yesterday-today-tomorrow". Then participants were given Cue Cards which contained pictures and questions regarding selected museum objects. They were instructed to search throughout the museum and locate the objects which appeared on their cards and then fill in the requested information. When the searchand-find work was completed, participants gathered around a History Line and Mute Map section. They placed completed search-and-find slips on the line according to the historical sequence and marked the location of the object (s) on the actual map. Participants also attended various role playing games in the museum. They were provided several role cards by the trainers containing detailed information on characters to be acted out and content to be used. The subjects of the cards were derived specifically from museum's timelines and objects. Trainers did not want participants to know details other than their own roles. Museum training days were concluded with the final assessment activities containing preparation of museum posters and brochures. Posters 
were produced using text and visuals in order to introduce or advertise an object within the museum or any theme chosen from the exhibition. Participants were divided into three main groups each of which was assigned one of the civilizations exhibited in the museum. Each group further divided itself into sub-groups, and each group was instructed to look for and observe items in the museum belonging to their assigned civilization. Groups took notes of items and objects they found in the museum relating to their civilization. They completed their excursion with the assistance of museum experts and then used the large sheets they were given to prepare a poster introducing the historical period they had been working on.

According to a majority of the participants which is also indicated in Table 3, museum activities were informative and enjoyable. While some thought they were difficult, long and exhausting.

As it is indicated in Table 4, participants perceived the museum as an enjoyable and informative place with activities such as Cue Cards, History Line and Mute Map. They also emphasized that they learned how to use the museum objects, follow museum rules and develop attention toward museum objects.

As it was stated in Table 5, warm-up games, frozen image and role play activities were also enjoyable according to participants. Not only being enjoyable but also being informative was the most important reason for the project team to include those activities through museum trains. In addition to that participants also stated that activities were informative that's because they were informed about the museum objects, historical backgrounds of them. They concentrated on that work in the museum atsmophere and did it as a group.

Participants filled out self assessment forms at the end of the museum activities. The details of the statements is indicated in Table 6. They evaluated their own learning process, particular level of their success and learning outcomes. The thoughts of participants were analysed with content analysis and the results are classified under the following headings: the mission of the museum bringing historical awareness, the museum's educational functions, learning and the museum objects and the emotional expressions that museum cause. $36 \%$ of children thought the mission of the museum was bringing historical awareness and they could learn the details of museum objects through education in the museum. They also thought museums had educational functions but people also could enjoy having museum education. They learned new games and activities in the museum but they also recognized the difficulty of adaptation, yet people could change their prejudice against museums through those activities and the Museum Training Programme emotionally affected them. They attended group works, empathized with old civilizations and they made museums interesting places for them as they stated below.

"Museums are rubbles for most people, to me its different since I am personally interested. Otherwise they are not charming places". (Boy, 9 years old)

"If we consider the visual materials are effective in learning we should visit the museums often or make them be visited by children". (Girl, 17 years old)

"I did not understand how the day passed in the museum. I will come here often". (Boy, 8 years old).

"I learned that the museums were children's playground". (Boy, 8 years old).

"We can learn how the points of view of human beings change and we also can be aware of the sophistication and values of the life". (Girl, 16 years old)

"To begin with, something, some changes should be made in order for children to love museums". (Boy, 13 years old)

"Museums should not be places where we tour hastily, they should be places where we understand and investigate the reasons". (Girl, 15 years old)

Although peer educators were aware of the educational and cultural functions of the museums, they described museums as places where they got bored to visit. When thoughts about museum education were content analyzed, peer participants were found to be strangers to the concept of museum education, and it was seen that they told about their ideal dreamt of situation instead of commenting on the reality. Statements can generally be classified as learning and entertainment, and as correcting inspirational limitations.

\section{Friendship Train through Museum Education Programme}

Following the completion of the Museum Training Programme and the Children's Museum Rooms, the group moved to another exciting stage of the project. An event called the "Friendship Train" was held in co-operation with the UN Joint Programme, Ministry of Family and Social Policies, Ankara University Interdisciplinary Museum Education Programme and the Ministry of Culture and Tourism. Based on the platform of children's 
Table 3. Statements about the activities cue cards, history line and mute map.

\begin{tabular}{ccc}
\hline What do you think about the activities? & & \\
\hline Statement & $f$ & $\%$ \\
Informative & 43 & 47.3 \\
Enjoyable & 36 & 39.6 \\
Difficult & 10 & 10.4 \\
Long and Exhausting & 7 & 7.2 \\
Total & 96 & 104 \\
\hline
\end{tabular}

Table 4. Statements about the things which participants learned from the activities.

\begin{tabular}{ccc} 
Statement & $f$ & $\%$ \\
\hline I learned how to use the objects and by whom they were made & 42 & 65.6 \\
I learned how enjoyable museums were & 25 & 17.2 \\
I learned how to be careful & 10 & 10.4 \\
I learned how to study and gather information about museum objects & 10 & 10.4 \\
I learned the museum rules & 9 & 9.3 \\
Total & 96 & 112.8 \\
\hline
\end{tabular}

Table 5. Statements about warm-up games, frozen image and role play.

\begin{tabular}{|c|c|c|}
\hline \multicolumn{3}{|c|}{ What do you think about the activities? } \\
\hline Statement & $f$ & $\%$ \\
\hline Enjoyable & 167 & 56.1 \\
\hline Informative & 32 & 20.7 \\
\hline Concentrated & 31 & 10.4 \\
\hline Suitable for group work & 21 & 7.8 \\
\hline Suitable for impersonation & 15 & 5.6 \\
\hline Total & 266 & 100 \\
\hline
\end{tabular}

Table 6. General statements of participants about museum activities.

\begin{tabular}{|c|c|c|}
\hline \multicolumn{3}{|c|}{ What do you learn from the museum education activities overall? } \\
\hline Statement & $f$ & $\%$ \\
\hline I recognized the details about museum objects & 39 & 36 \\
\hline I understood that museum education was enjoyable and playful & 18 & 16.6 \\
\hline I recognized that I had to be careful and attentive in the museum & 11 & 10 \\
\hline I learned new games and activities which could be played in the museum. & 10 & 10 \\
\hline I understood how life was very difficult for people centuries ago & 10 & 9.25 \\
\hline I learned to attend to group works & 10 & 9.25 \\
\hline I learned how to do a presentation & 10 & 9.25 \\
\hline Total & 108 & 100 \\
\hline
\end{tabular}


rights, the project aimed to raise children's awareness of their cultural heritage and its safeguarding, as well as, to communicate the activities of the Provincial Committees of Children's Rights. After about two years of planning and preparation, on 18 April 2011, the Friendship Train was waiting at Haydarpaşa Terminal in Istanbul, Turkey with 32 peer educators ready for a $2000 \mathrm{~km}$ journey. Totally 74 passengers rode the train to Kars. The eight-car Friendship Train was allocated to children pursuant to a protocol between the Ministry of Family and Social Policies and the Turkish State Railways. It stopped in Eskişehir, Ankara, Sivas and Erzurum and various activities were held in each city along the way. After the warm welcoming of an enthusiastic crowd holding apple candies at Eskişehir, the train continued on its journey to the capital, Ankara. There, passengers visited Anttkabir and a training session was held at the Cer Modern Contemporary Art Museum and attended museum education activities. In Sivas, after visits to Old Buruciye Madrasah (Theological School) and the Congress Museum, a special museum training session was held at the Sivas Archaeological Museum with the participation of Sivas Committee of Children's Rights. On 21 April 2011, the Children's Museum Room was opened in Erzurum with the participation of children and adults from Erzurum.

The train reached its last stop, Kars, on 22 April 2011. The Friendship Train's journey ended with a feast at the Kars Culture House of Minstrels. A journal about the Friendship Train was compiled into a book in both Turkish and English. Also, in order to record all aspects of this educational journey, a short movie was produced from video shot by children from the Erzurum and Kars Committees of Children's Rights. Peer educators met children in the cities in which the train stopped, and they learned more about what these children's lives were like, as well as, and what issues they were facing. Also, visits were made to discover the local museums of those cities. There were museum education activities in the train during their journey. Peer educators also used the museum education package during their journey on a train. The package included an innovative peer-to-peer module, that had already attracted international attention, which the boys and girls aboard the train were the first to use. The same partners had also collaborated to furnish and decorate children's rooms in museums in Kars and Erzurum, so that visiting children would have space for their activities. The energy and enthusiasm of both children and adults that was created by the Museum Training Programme made it possible to pioneer the opening of Children's Museum Rooms in Kars and the neighbouring province of Erzurum. The rooms were set up with the contributions and support of museum managers in both provinces. The first children's museum room was opened in the Kars Archaeology Museum on 17 January 2011, while the room in Erzurum was opened in Atatürk’s House Museum on 21 April 2011.

\section{Compilation of the Museum Training Modules into a Book}

Methods, techniques and activities used in museum trainings were further developed into a "Museum Training Package" comprising five books of different content, so as to provide source material for similar activities to be carried out in other parts of the country. All of the components of this package were prepared to inform teachers, museum staff and children about the process of developing awareness of cultural heritage through peer training in museums and subsequent extension work by children. The books contain information on how museum training methods, techniques and activities are to be used as well as the basic skills that need to be imparted to children participating in these activities. Books have been prepared for the purpose of developing national and universal cultural awareness in children and adolescents through peer education.

The objectives of the museum training package to be used by children as peer trainers are as follows: Implementing the programme in line with the broad goals of the Turkish National Education System, taking due account of the present knowledge and environmental circumstances of your peers as well as existing curricula, helping peers to advance their knowledge, skills and values and to assimilate culture through social, cultural, educational, scientific, sporting and artistic activities, ensuring that peers develop as self-confident individuals capable of thinking systematically and creatively, taking initiative, conducting work in a planned way and expressing feelings and sentiments in aesthetic forms, encouraging peers to think and investigate creatively and critically by ensuring efficient utilization of tools and instruments, resources and time and by developing a taste for the arts.

\section{Conclusion}

While working on different areas of learning in the museum training package, approaches to measurement and assessment were built on multiple-intelligence theory, constructive and project approaches as well as active 
learning methods. The museum training package started from these themes; games, cultural heritage and daily life. The contents of courses such as Turkish, life skills, social skills, science and technology, visual arts and artistic activities given at primary and secondary schools were also taken into account. In museum training, anything, whether abstract or concrete, that exists in the inner world and close environment of the student can be taken as a topic. However, any selected theme must overlap with the perceptual, intuitive and interpretative competence of the student, as well as, his/her past achievements. The theme is a dimension that is given existence and form by dissecting it away from the topic or being inspired by it. The content is the message which the student wants to convey and the source of aesthetic concern that he/she wants to awake in their counterpart.

A workshop was held in Ankara from 24 to 25 October, 2011 to discuss the sustainability of the Museum Training Programme at the end of the project. The goal of the workshop was to create a permanent model by which children will benefit from the museum activities. The workshop found answers to the sustainability of the museum education projects in other cities in Turkey. It also aimed to answer the question how we can implement the training programmes in the best manner, taking into consideration contributions from both children and adults. It also emphasize the ways of preserving the children's museum rooms and integrating children with the museum rooms.

\section{References}

Ambrose, T., \& Paine, C. (2006). Museum Basics (2nd ed.). London: Routledge.

Eagleton, T. (2003). After Theory. New York: Basic Books.

Gingell, J. (2006). The Visual Arts and Education. Great Britain: Philosophy of Education Society of Great Britain.

Grek, S. (2009). "In and against the Museum”: The Contested Spaces of Museum Education for Adults. Discourse: Studies in the Cultural Politics of Education, 30, 195-211. http://dx.doi.org/10.1080/01596300902809237

Hooper-Greenhill, E. (1991). Museum and Gallery Education. Leicester: Leicester University Press.

Hooper-Greenhill, E. (1994). Museum Education: Past, Present and the Future. In R. Miles, \& L. Zavala (Eds.), Towards the Museum of the Future: New European Perspectives. London: Routledge.

Hooper-Greenhill, E. (1999). The Educational Role of the Museums. London: Routledge.

Hooper-Greenhill, E. (2000). Museums and the Interpretation of Visual Culture. London: Routledge.

İlhan, C. A. (2009). Educational Studies in Turkish Museums. Procedia Social and Behavioral Sciences, 1, 342-346. http://dx.doi.org/10.1016/j.sbspro.2009.01.064

Karadeniz, C. (2012). A Step Closer to Children's Museum. In F. Doyran (Ed.), Research on Teacher Education and Training (pp. 229-241). Athens: Athens Institute for Education and Research.

Keene, S. (2005). Can Museums Survive the Postmodern? Archaeology International, 9, 36-39. http://dx.doi.org/10.5334/ai.0910

Lyon, D. (1999). Postmodernity (2nd ed.). Buckingham: Open University Press.

Schubert, K. (2000). The Curator's Egg: The Evolution of the Museum Concept from the French Revolution to the Present Day. London: One-Off Press.

Talboys, G. (2006). Museum Educator's Handbook (2nd ed.). UK: Ashgate Publishing.

Weil, S. (1990). Rethinking the Museum and Other Meditations. Washington: Smithsonian Institution. 
Scientific Research Publishing (SCIRP) is one of the largest Open Access journal publishers. It is currently publishing more than 200 open access, online, peer-reviewed journals covering a wide range of academic disciplines. SCIRP serves the worldwide academic communities and contributes to the progress and application of science with its publication.

Other selected journals from SCIRP are listed as below. Submit your manuscript to us via either submit@scirp.org or Online Submission Portal.
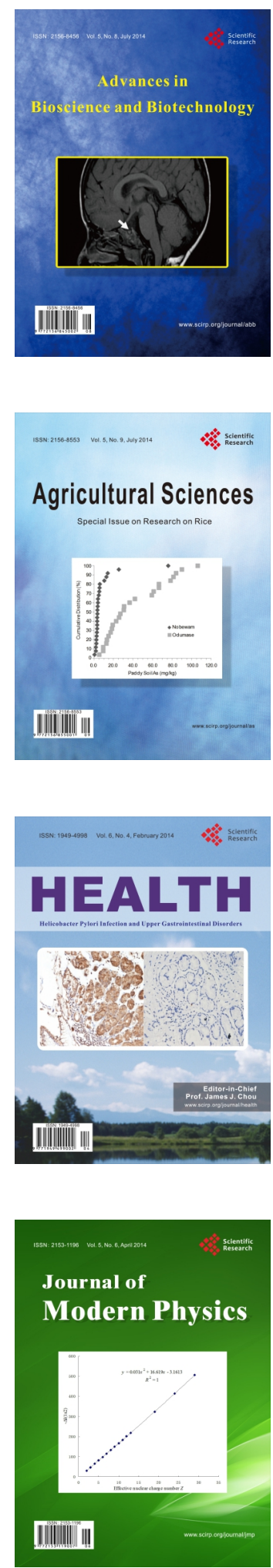
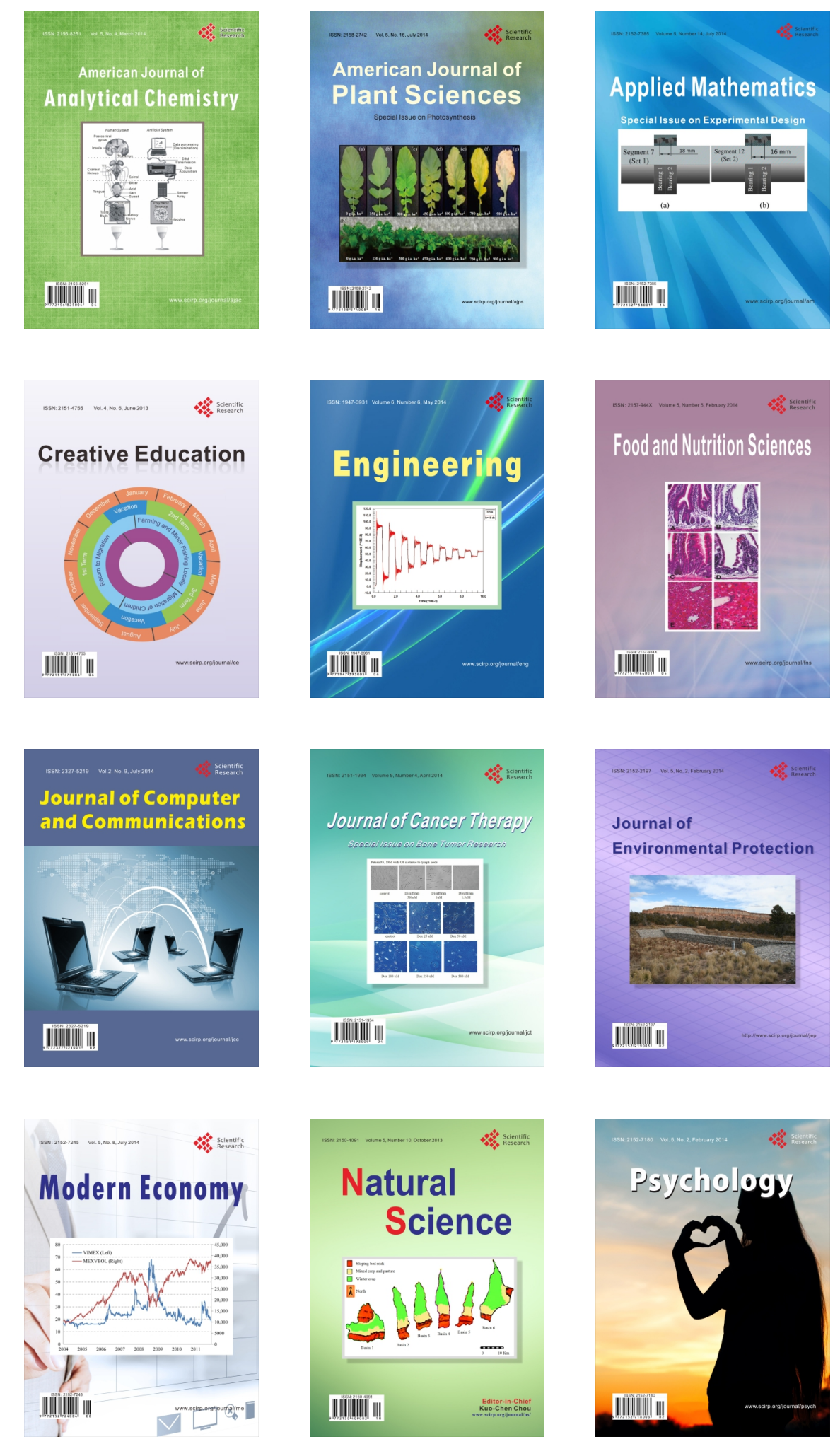